\title{
Spread Components in the Hungarian Forint-Euro Market*
}

\author{
Michael Frömmel, Ghent University, BELGIUM ${ }^{\mathrm{a}, \mathrm{b}}$ \\ Frederick Van Gysegem, Ghent University, BELGIUM ${ }^{\mathrm{a}}$
}

This version: February 15, 2011

\begin{abstract}
We apply the spread decomposition model by Huang and Stoll (1997) to a new dataset on the Hungarian Forint/Euro interbank market. In contrast to previous results we cover a minor market over a long time span. We find a significant inventory effect, which can be explained by the low number of trades per day and thus the long time between offsetting trades. The trading volume increased gradually during our sample period and coincided with a decreasing spread. We find that spread size increases significantly with trade size, in contrast to previous research on the customer market. We show that this increase is caused by rising inventory holding and adverse selection costs.

Overall this work confirms the predictions from various theoretical models on a small and less liquid market. When comparing with other results the size of the market, institutional differences between markets and specificities of a dataset seem to play an important role.
\end{abstract}

JEL: F31, G15

Keywords: microstructure, foreign exchange, spread, Hungary, inventory, adverse selection

*We would like to thank the Bijzonder Onderzoeksfonds (Special Research Fund) of Ghent University for financial support and the Magyar Nemzeti Bank (Hungarian National Bank) for sharing the data. For helpful suggestions we would like to thank Andros Gregoriou, Alexander Mende, Lukas Menkhoff, two anonymous referees and seminar participants at the Leibniz Universität Hannover, Germany, the CICM Conference (London Metropolitan University, UK), and the workshop "Microstructure of Financial Markets" (Cass Business School, UK).

${ }^{a}$ Department of Financial Economics, Ghent University, W. Wilsonplein 5D, 9000 Ghent, Belgium

b Corresponding author: +32-(0)9-264-8979, michael.froemmel@UGent.be 


\section{Spread Components in the Hungarian Forint-Euro Market}

\section{Introduction}

Since a well-functioning foreign exchange market is of crucial importance for the economy, which is particularly true in the case of small open economies as most of the Central and Eastern European Countries (CEEC), there is a deep interest in the way it works. The microstructure approach to foreign exchange (see Lyons 2001) allows for market frictions, like imperfect information and heterogeneous agents, and tries to explain the processing of news (price discovery), liquidity and transaction costs. In this context the bidask spread and its determinants play a crucial role. The decomposition of the bid-ask spread on financial markets has attracted increasing attention during the last decades for several reasons. It is important as an indicator of market liquidity and competition, but also reflects the way information is processed in the market. This is important because a different market structure changes the "game played between the market participants" (Rime 2003, p. 471). It is therefore relevant for market participants, but also for the operators of markets in terms of an evaluation of the market design. The microstructure approach to foreign exchange markets has made some promising steps towards a better understanding of the foreign exchange market.

The bid-ask spread is the difference between the price an active buyer must pay, and the revenue an active seller receives. ${ }^{1}$ It is common to relate the size of the spread to various kinds of cost components: the order processing (or handling) component, the adverse selection component and the inventory holding component. ${ }^{2}$ While most early papers focused on order processing and adverse selection costs, the inventory holding component has recently gained much attention.

We contribute to the literature by exploiting a new dataset on the Hungarian foreign exchange market. Since this is the first detailed dataset available for a transition economy, it enables us to compare the spread components on a small and less liquid market to those of previous studies that mainly focused on major currencies. One may expect that components

\footnotetext{
${ }^{1}$ One counterpart of a trade can be viewed as an active party and one counterpart as a passive party. The party that posts quotes and waits until they will be hit by another market participant is the passive party. The party that matches an existing limit order by a market or another limit order is the active party.

${ }^{2}$ One may also distinguish components for the option effect and non competitive pricing (see for example Stoll 2003). This is, however, less common. Therefore we do not follow these directions. We see the option effect as part of the adverse selection component.
} 
directly related to the liquidity of the market, namely the order processing and the inventory holding component, will be more important in transition economies than in the foreign exchange market for major currencies. There may also be more private information on a market on which trading is less intensive. We investigate whether this is reflected in a higher adverse selection component. Furthermore the sample size of our dataset exceeds the size of most other datasets used in the literature by far (see also the comparison in Table 4). Finally, we will re-examine the relation between trade size and spread, which has been controversially discussed in the literature and which we will shortly review in section 3 .

The paper proceeds as follows: The subsequent section 2 gives some key facts on the foreign exchange market and our dataset on the Hungarian Forint/Euro market. In section 3 we will briefly discuss the components of the bid-ask spread and review the literature for the foreign exchange market. Section 4 presents the widely used spread decomposition model by Huang and Stoll (1997), hereafter referred to as HS1997. Section 5 presents our empirical results and Section 6 summarizes and concludes.

\section{The Foreign Exchange Market and Data Description}

The foreign exchange market is a two-tier market. Trades on the foreign exchange market can be divided into customer trades, i.e. trades between a bank and customers (the ultimate end-users, for instance importing and exporting firms, hedge funds, governments and central banks) and interbank trades. In the following we focus on the interbank market, as the price formation takes place here. Customers do not have access to this interbank market.

In the interbank market trades may be performed directly on a bilateral basis, or indirectly using brokers. While voice brokers were dominating in the past, the majority of trades are nowadays done via electronic brokering systems. Since their introduction in 1992 their share in total transaction volume has steadily increased, depending on the country, from 4 to 6 per cent in 1995 to more than 55\% of the interbank market in 2010 (BIS 1996, BIS 2010).

Furthermore the foreign exchange market works continuously 24 hours per day and seven days per week. While this holds for the major currencies, the picture may be substantially different for less important currencies, such as the HUF, accounting during our sample period in 2004 for only $0.22 \%$ of the global turnover on the FX market (BIS 2005). For many small currencies there is no trading activity outside the business hours, but even during day these markets are characterized by a low degree of liquidity. 
Further characteristics of the foreign exchange market are the decentralized trading and a high number of dealers providing liquidity, compared for example with specialists on equity trading floors. Particularly the decentralized structure has supported the emergence of electronic brokerage systems as they provide an efficient matching to decentralized markets. Accordingly the foreign exchange market was one of the first to introduce electronic trading (see Rime 2003 for a detailed overview on electronic currency trading). Electronic trading has been the most remarkable change in the structure of the foreign exchange market and has led to a substantially higher price transparency. Dealers can now observe the best quotes (although not the whole order book) and information about the most recent transactions.

There are two main platforms competing in the foreign exchange market: Reuters D3000 and EBS (Electronic Broking System). In our analysis we rely on the Reuters D3000 system. As an electronic limit order book it contains buy and sell orders in a price-time priority. Euro sale and purchase offers are placed at limit prices. Besides these limit orders, consisting of the maximum respectively minimum price and the quantity offered to be traded, it is also possible to place a market order, i.e., an order without a specified price. They are immediately matched with the best corresponding limit order and thus more aggressive. Therefore the following matches may lead to a trade: two limit orders that are matched up by the system, or a market order that is matched up with the best limit order on the opposite side.

Our dataset consists of all quotes, i.e., limit and market orders, on the HUF/EUR interbank market that have been placed during the years 2003 and 2004 via the Reuters D3000 brokering system. We observe the price, the quantity in Euro that was offered or asked, whether it was a market or a limit order and the exact time when the order was placed and when it disappeared. We observe whether the order was withdrawn or whether it was executed, i.e., matched with another limit or market order. Using this information we can identify the executed trades that we need for the estimation of the empirical model by HS1997 (see Section 4). For the evolution of the exchange rate and traded volumes, see Figure 1. Because at this time the competing system EBS did not offer services for the HUF/EUR market, the dataset covers the complete trading on electronic brokerage platforms, and thus the major part of market activity.

For descriptive statistics of the dataset see Table 1. An in-depth description of the dataset can be found in Gereben and Kiss M. (2006).

Since there are almost no quotes during night we only use the trades executed during the daytime (9 a.m. - 5 p.m. local time) and executed on days with a sufficiently high number of 
trades. This last restriction is implemented by neglecting days with trading volumes below 100 million EUR (with these 100 million EUR being roughly half of the average trading volume per day) to avoid potential biases due to low trading activity.

Our dataset contains 722 days on which orders were placed. By cancelling out the days without any trade at all (weekends and public holidays) there remain 516 days. The above mentioned constraint for days with a low trade volume restricts the sample to 496 days. While the procedure seems to be restrictive at first sight, our selected sample covers $99.74 \%$ of the total volume traded over 2003 and 2004.

\section{The analysis of spreads}

This section describes the different components of the spread. For a detailed discussion of these components see Stoll (2003).

The order processing component $(O P C)$ is the cost component that is most closely linked to the provision of services. The OPC includes the costs of labour and capital needed to participate in the market, such as the floor space rent, computer and informational service, and labour costs. It is often argued that in highly competitive markets (unlike the HUF/EUR market) order processing costs are irrelevant, since the bid/ask spread should equal the expected marginal cost of supplying liquidity.

The inventory holding component (IHC) compensates dealers for taking an unwanted inventory. If a dealer located in the Euro area for example buys Hungarian Forint, he has to carry inventory costs. These costs mainly stem from two sources: First, there may be opportunity costs of tying up funds in the inventory. However, one may assume that the opportunity costs of the inventory are low on foreign exchange markets in comparison to equity markets. Second, a dealer experiences a substantial amount of risk: The price may change due to the arrival of news before he is able to offset his undesired inventory in Forint. Thus, the inventory holding component represents this fundamental risk. The magnitude of the inventory costs depends on price volatility, since higher volatility means a higher risk of an undesired price change, and on the expected time the inventory has to be held. Both are, at least to some extent, determined by the trading frequency. Therefore the inventory holding component is obviously expected to be higher on small, less liquid markets as the HUF/EUR market where on average only every three minutes one deal is executed, whereas the time between subsequent trades on major markets does not span more than a few seconds. 
Finally, market participants face the risk of trading with a counterpart that is better informed. If an investor has superior information, he will sell Forint if he has information justifying a lower price than the current one, or vice versa. The market participants may take this possibility into account when offering their quotes and ask an additional compensation, to which we will refer as the adverse selection component (ASC) of the spread. The existence of an ASC is justified by a couple of theoretical papers, such as Kyle (1985), Easley and O'Hara (1987) or Admati and Pfleiderer (1988). Besides these theoretical papers, empirical research provides evidence for the existence of an ASC (see Table 4).

Note the fundamental difference in the nature of the IHP and the ASC (Stoll 2003): Inventory costs occur due to public and symmetric information that becomes available after the trade, in which inventory has been acquired. Of course the potential losses and gains resulting from holding the inventory must cancel out on average, but the risk-averse dealer will nevertheless ask a premium to get compensated for the risk he takes. In contrast to the inventory costs, the ASC results from private and asymmetric information before the trade takes place. It is thus the risk to deal with a counterparty owning superior information.

Previous research on foreign exchange market spreads focused on larger, more liquid markets. In a seminal paper Lyons (1995) applies microstructure models to the USD/DEM market and finds evidence for both an inventory and an asymmetric information effect, and again evidence for inventory control in Lyons (1998). The existence of both effects in the data is supported by Yao (1998). In contrast, Mende (2005) only finds a significant adverse selection component, but no consistent inventory effect. Using a VAR approach, Payne (2005) finds that about 60 per cent of the spread is due to asymmetric information. All these studies focus on the most liquid Deutsche Mark (Euro)/US Dollar market. McGroarty et al. (2007) compare the results achieved by the HS1997 model for different major currencies (Euro, US Dollar, Japanese Yen and Swiss Franc).

In contrast few studies have been performed on spreads on smaller foreign exchange markets. An exception is Bjønnes and Rime (2005), who investigate the behaviour of a Norwegian Koruna/Deutsche Mark dealer. They find again a significant asymmetric information component, but no inventory effect. To our knowledge there is no similar work on Central- and Eastern European countries.

Another strand of literature deals with the relationship between order size and the bidask spread. There are essentially three theoretical directions which can be followed to link order size and spread: processing cost models, inventory risk models and information cost models. While the first direction suggests that increasing trade size does not increase spreads 
(see Stoll 1978, Hartmann 1999), inventory risk models and information cost models conclude that there should be a positive relation between trade size and spreads (see for instance Ho and Stoll 1981 for inventory costs, Kyle 1985, Admati and Pfleiderer 1988 for adverse selection costs). Similarly, the empirical research on the relation between trade size and spread has provided mixed results. While Lyons (1995) finds a positive relation between order size and spreads, most studies conclude that there is little or no relationship between spread and order size (Yao 1998, Bjønnes and Rime 2005). The distinction between the customer and the interbank market is here also important: On the customer market strategic considerations are more important when setting spreads (Naik et al. 1999). This difference between the customer and interbank market is also empirically supported: On the customer market a negative relation between trade size and spread size is found in the trading behaviour of a German bank on the USD/EUR market (Osler et al. 2010). For an online FX dealer on the interdealer USD/EUR market the spread is found to be independent from order size (Ding 2009). Mende (2005) distinguishes between commercial customers (mainly nonfinancial corporations), financial customers (such as investment funds), and interbank trades. He finds that the asymmetric information component of spreads increases with order size only for more informed counterparties, i.e., financial customers and other banks, although the spreads for these trade partners are smaller than those for commercial customers.

\section{Empirical Model}

There have been various attempts to estimate the different spread components, which can be broadly categorized into covariance based models (Stoll 1989, George et al. 1991) and models based on trade indicators (e.g. Madhavan et Smidt 1991, HS 1997). The models by Madhavan and Smidt (1991) and HS1997 have become the workhorse of spread decomposition. We apply the well established HS1997 model, which has the advantage of being widely used and at the same time to provide estimates for the adverse selection and the inventory holding component separately in its most advanced form (in contrast to the Madhavan and Smidt 1991 model). The HS1997 is based on the assumptions shown in the following three equations (see HS1997):

$$
\mathrm{V}_{\mathrm{t}}=\mathrm{V}_{\mathrm{t}-1}+\alpha \cdot \mathrm{S} / 2 \cdot \mathrm{Q}_{\mathrm{t}-1}+\varepsilon_{\mathrm{t}-1}
$$


Equation (1) means that the unobservable fundamental value $V_{t}$ equals the fundamental value $\mathrm{V}_{\mathrm{t}-1}$ of the previous period plus the change in value $\alpha \cdot \mathrm{S} / 2 \cdot \mathrm{Q}_{\mathrm{t}-1}$ that is due to private information, reflected in the previous trade, plus the change in value $\varepsilon_{\mathrm{t}-1}$ that is due to public information. The component $\alpha \cdot S / 2 \cdot Q_{t-1}$, where $S / 2$ is the half spread and $Q_{t}$ is a trade indicator, taking the value 1 , if the trade was buyer initiated and -1 if it was seller initiated ${ }^{3}$, can be derived from the models by Copeland and Galai (1983) and Glosten and Milgrom (1985). Therefore, $\alpha$ is the proportion of the half spread due to asymmetric information.

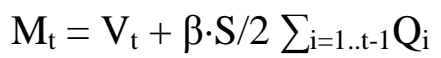

According to equation (2) the midpoint $\mathrm{M}_{\mathrm{t}}$ of the bid-ask spread differs from the fundamental value by the cumulated inventory, i.e. the cumulated inventory on the respective day. ${ }^{4}$ If there were neither inventory costs nor private information the midpoint was equal to the fundamental value. Equation (2) is based on inventory theories of the spread (e.g. Ho and Stoll 1981) and means that liquidity providers adjust their midpoints on the basis of accumulated inventory in order to induce inventory equilibrating trades. Thus, $\beta$ is the proportion of the half spread due to inventory holding costs.

$$
P_{t}=M_{t}+S / 2 \cdot Q_{t}+\eta_{t}
$$

$\mathrm{P}_{\mathrm{t}}$ is the quote on the market, and $\mathrm{M}_{\mathrm{t}}$ is the observable midpoint between bid and ask price. Equation (3) means that the HUF/EUR quote fluctuates around the midpoint by the half-spread, depending on whether we observe a buy or sell. ${ }^{5}$

Differencing equation (2) and substituting $\Delta \mathrm{V}_{\mathrm{t}}$ by its expectation $\alpha \cdot \mathrm{S} / 2 \cdot \mathrm{Q}_{\mathrm{t}-1}$ (equation 1) and substituting the whole expression into the differenced version of equation (3) leads then to a two-way decomposition by the following regression:

\footnotetext{
3 A trade is buyer initiated, if a buyer hits an existing limit sell order from the order book with a buy market order or by placing a limit buy order that is matched by the system with an active limit sell order.

${ }^{4}$ Note that equation (2) assumes trades of the standard size one. Since on the HUF/EUR market $85 \%$ of all trades are of the minimum size of 1 million EUR this assumption seems to be justified.

${ }^{5}$ The estimated spread does not necessarily equal the quoted spread (HS 1997). The difference with observed posted spreads is that the estimated spread reflects trades inside the spread but outside the midpoint.
} 


$$
\Delta \mathrm{P}_{\mathrm{t}}=\mathrm{S} / 2 \cdot\left(\mathrm{Q}_{\mathrm{t}}-\mathrm{Q}_{\mathrm{t}-1}\right)+\lambda \mathrm{S} / 2 \cdot \mathrm{Q}_{\mathrm{t}-1}+\mathrm{e}_{\mathrm{t}}
$$

Here $\Delta \mathrm{P}_{\mathrm{t}}$ is the price change between two subsequent trades. Equation (4) may therefore be interpreted as the (private) information that is potentially incorporated in the last trade. $\mathrm{S} / 2 \cdot\left(\mathrm{Q}_{\mathrm{t}}-\mathrm{Q}_{\mathrm{t}-1}\right)$ is the price movement due to switches between buy and sell orders, thus a jump between the two edges of the spread, if a buyer initiated order is followed by a seller initiated order and vice versa. The joint effect of asymmetric information and inventory holding is captured by $\lambda$, and $e_{t}$ reflects the arrival of public information. For details of the derivation see HS1997.

In a second step, an analysis for different trade sizes can be useful. To derive equation (4), the assumption, given by equation (3), was used. As trade size is not included in equation (3), it implicitly states that the spread is independent of the trade size. Explicitly considering trade size in all assumptions is thus necessary. For three size categories, this results in the following regression equation:

$$
\begin{aligned}
& \Delta \mathrm{P}_{\mathrm{t}}=\left(\mathrm{S}^{\mathrm{s}} / 2\right) \cdot \mathrm{D}^{\mathrm{s}}(\mathrm{t}) \cdot \mathrm{Q}_{\mathrm{t}}+\left(\lambda^{\mathrm{s}}-1\right) \cdot\left(\mathrm{S}^{\mathrm{s}} / 2\right) \cdot \mathrm{D}^{\mathrm{s}}(\mathrm{t}-1) \cdot \mathrm{Q}_{\mathrm{t}} \\
& +\left(\mathrm{S}^{\mathrm{m}} / 2\right) \cdot \mathrm{D}^{\mathrm{m}}(\mathrm{t}) \cdot \mathrm{Q}_{\mathrm{t}}+\left(\lambda^{\mathrm{m}}-1\right) \cdot\left(\mathrm{S}^{\mathrm{m}} / 2\right) \cdot \mathrm{D}^{\mathrm{m}}(\mathrm{t}-1) \cdot \mathrm{Q}_{\mathrm{t}} \\
& +\left(\mathrm{S}^{\mathrm{l}} / 2\right) \cdot \mathrm{D}^{\mathrm{l}}(\mathrm{t}) \cdot \mathrm{Q}_{\mathrm{t}}+\left(\lambda^{1}-1\right) \cdot\left(\mathrm{S}^{\mathrm{l}} / 2\right) \cdot \mathrm{D}^{\mathrm{l}}(\mathrm{t}-1) \cdot \mathrm{Q}_{\mathrm{t}}+\mathrm{e}_{\mathrm{t}}
\end{aligned}
$$

$\mathrm{D}_{\mathrm{s}}$ is a dummy variable that equals 1 if the size of the trade falls in the "small" category and 0 when this is not the case. The same applies for $D_{m}$ and $D_{1}$.

As equation (4) does not allow distinguishing between the inventory effect and the asymmetric information effect, Huang and Stoll suggest taking the potential serial correlation between trade flows into account. This three-way decomposition (for the derivation we again refer to HS 1997) is performed by simultaneous estimation of the following model:

$$
\begin{gathered}
E\left(Q_{t-1} \mid Q_{t-2}\right)=(1-2 \pi) Q_{t-2} \\
\Delta P_{t}=S / 2 \cdot Q_{t}+(\alpha+\beta-1) \cdot S / 2 \cdot Q_{t-1}-\alpha \cdot S / 2 \cdot(1-2 \pi) Q_{t-2}+e_{t}
\end{gathered}
$$


Here $\pi$ is the estimated probability of a trade reversal. This probability is calculated using the potential serial correlation mentioned above. The model allows us to decompose the joint effect $\lambda=(\alpha+\beta)$ of asymmetric information $(\alpha)$ and inventory holding $(\beta)$ into its components. Equations (4) and (6-7) serve as our baseline regressions in the subsequent analysis.

\section{Empirical Results}

This section presents the results from the two-way and three-way decomposition of the spread on the Hungarian Forint/Euro market in 2003-2004 as described in section 2. All estimations are done with the Generalized Method of Moments (GMM) of Hansen (1982) and the Newey and West (1987) correction of the covariance matrix for heteroscedasticity and autocorrelation of unknown form.

The results for the basic two-way decomposition as in HS1997 are displayed in Table 2. The (estimated) average spread is 0.106 HUF for the whole sample period with the order processing component accounting for $42.58 \%$ of the spread and the sum of the adverse selection component and inventory holding component for $57.42 \%$. The spread implies a revenue per one million Euro round trade of roughly $420 \mathrm{EUR}$, which seems to be reasonable. From the most comparable study by McGroarty et al. (2007) revenues of about 44 to 206 EUR, depending on currency and sample period, can be derived. According to their results the revenues were highest on the EUR/JPY market in 1999 (206 EUR) and lowest for the DEM/CHF market (44 EUR) in 1998. The revenues on the EUR/USD were also quite small (between 69 and 75 EUR). The higher revenue on the HUF/EUR market is in line with the notion of a smaller market.

Applying the three-way decomposition from HS1997 the estimated spread is 0.107 HUF on average for the whole sample period. When we decompose the spread in three components by using equations (2) and (3), we find that the inventory holding costs account for $40.09 \%$ of the spread. The order processing costs account for $38.34 \%$ of the spread and the adverse selection costs for $21.57 \%$ of the spread (see Table 3 ).

Although the share of the inventory holding premium on the HUF/EUR market is of comparable size as found by McGroarty et al. (2007) for major markets, it should be stressed that it is larger in absolute terms, due to the larger spread on the HUF/EUR market. While according to their results the share of inventory effects in the total costs of a one million EUR 
round trade normally does not exceed $87 \mathrm{EUR}^{6}$ we find costs of $168.38 \mathrm{EUR}$ (40.09\% of 420 EUR). Thus, inventory holding costs do play a prominent role on this market. This is related to the fact that we are dealing with a smaller and less liquid market. Additionally, this finding can be related to a higher prevalence of carry trades on the HUF/EUR market, due to the interest differential between both currencies during our sample period. Brunnermeier et al. (2009) provide extensive and convincing evidence of a higher currency crash risk for currencies involved in carry trading. They show that investment currencies are vulnerable to massive and sudden unwinding of carry trade schemes when the liquidity dries up for the carry-trade investors. They also find that insurance against downside risk becomes more expensive during and after this unwinding. For a trader this means that the inventory holding cost for HUF is higher than for currencies which are not involved in carry trades. Unfortunately we are not able to observe the share of carry trades in the total trading volume.

In order to check the robustness of these results the spreads are decomposed for two obvious subsamples, namely the trades executed in 2003 and the trades executed in 2004 (see Table 2). Starting again with the two-way decomposition the spread is estimated to be 0.133 HUF for 2003, whereas it declines in 2004 to 0.086 HUF. This decrease is statistically significant. ${ }^{7}$ The sum of the adverse selection and inventory holding component accounts for $56.43 \%$ of the total spread in 2003 and for $57.87 \%$ of it in 2004. Despite the slight relative increase for this combined component it lowers in absolute value with one third in 2004 compared to 2003. The order processing component slightly decreases relatively: from $43.57 \%$ in 2003 to $42.13 \%$ in 2004 . The absolute size of the order processing component decreased by $37.93 \%$ between 2003 and 2004 .

We performed the same analysis for each half year in order to get a better view on the evolution of the spread and its components during the observed period (See Table 2). Figure 2 visualizes the results of this analysis using the two-way decomposition. The estimated spread declines each half-year. This decline is statistically significant between the second half of 2003 - first half of 2004 and first half of 2004 - second half of 2004. Both spread components decline in absolute terms during every half year period, except for the slight increase in the sum of the adverse selection component and inventory holding component over the second half year of 2003 .

\footnotetext{
${ }^{6}$ The only exception is the EUR/JPY in the post EMU sample with 134 EUR.

${ }^{7}$ We verified the statistical significance of spread changes in this paragraph by doing a t-test on year-specific dummies in an adapted regression setup. In this case for example we estimated $\Delta \mathrm{P}_{\mathrm{t}}=\mathrm{S} / 2 \cdot\left(\mathrm{Q}_{\mathrm{t}}-\mathrm{Q}_{\mathrm{t}-1}\right)+\mathrm{S} / 2 \cdot\left(\mathrm{Q}_{\mathrm{t}}-\mathrm{Q}_{\mathrm{t}-1}\right)$ $\cdot D_{2004}+\lambda \cdot S / 2 \cdot Q_{t-1}+e_{t}$ A t-test on the coefficient of the dummy (here: $D_{2004}$ ) indicates whether the difference between both years is statistically significant.
} 
When we apply the three-way decomposition we again find the absolute spread to be decreasing each half year. This decrease is statistically significant between the second half of 2003 - first half of 2004 and the first half of 2004 - second half of 2004. The relative inventory holding component decreases quite strongly, especially over the last half year. The relative adverse selection component increases strongly over time: in the second half of 2004 it is almost twice as big as in the first half of 2003. The order processing cost, again, decreases as in the two-way decomposition.

Both approaches yield declining spreads over time. An explanation for this could be provided by the increased trading volume in the course of the deepening market over the sample period. In the two-way decomposition both components tend to decrease over time in absolute terms, whereas over the same period the average daily trading volume went up from 178.52 million Euros in 2003 to 202.67 Euros in 2004. This result is in line with theoretical models predicting that higher trading activity leads to lower spreads, since higher trading activity lowers waiting costs (Parlour 1998, Foucault et al. 2005, Rosu 2009).

On the level of individual spread components, theory suggests that there is a direct negative effect of the trading volume on the order processing component and the inventory holding component (Stoll 1978). ${ }^{8}$ In contrast, there is no direct relation between trading volume and the adverse selection costs, since in these models there is only a role for the proportion of informed traders in the market (Glosten and Milgrom 1985) and size of an individual trade (Easly and O'Hara 1987). In our three-way decomposition results we find each half-year an absolute decrease in inventory holding costs and order processing costs per unit traded (except for a minor increase in inventory holding costs in the second half of 2003), whereas we do not find a decrease in absolute terms of the adverse selection costs over time. In our data we find consequently support for the theoretical relationship between trading activity and the spread components. One should, however, note that there may be a bidirectional causality between trading activity and spread size, i.e. higher trading activity may lead to lower spreads, but lower spreads may also attract traders and therefore increase trading activity. Previous work on the Helsinki stock market dealt with this endogeneity and showed that the linkage can be significant in both directions, both economically and statistically (Linnainmaa and Roçu 2009). Addressing the endogeneity issue falls beyond the scope of the model we use in this paper. A second reason for the decrease of the spread may

\footnotetext{
${ }^{8}$ For the order processing component this is the consequence of the possibility to distribute the fixed costs over more trades. The inventory holding component decreases, because the time between two consecutive trades becomes shorter and the dealer can revert his position at lower risk.
} 
be the lower volatility throughout the year 2004. In contrast, 2003 was characterized by the turmoil on the HUF/EUR market, including the speculative attack against the Forint in January, the shift of the band in June and the increase of the interest rate by the central bank in December (see Gereben and Kiss M. 2006). Still, this volatility effect would not be consistent with the decreasing absolute order processing component.

As an extension we verify the relation between spread and trade size, by performing the two-way decomposition for different trade sizes (equation 5). The information on the frequency of trades provided in Table 1 suggests that it is reasonable to split up the trades into trades of 1 million Euro (the minimum trade size: small trades), trades exceeding 1, but less than 3 million Euro (medium trades) and trades of 3 million Euro or more (large trades). Small trades account for more than 80 per cent of all trades.

Our results for the HUF/EUR market are presented in Table 2 and Figure 3. We find that the spread is significantly ${ }^{9}$ and positively related to trade size. We verified whether the difference in spread size between the different trade size categories could be driven by the fact that large trades loose relative importance in 2004, when the overall spread size decreased on the market, by estimating trade-specific spreads for each year separately. The significant difference between the estimated spread on small and large trades remained. For 2003 the estimated spreads on small and large trades were respectively 0.13 HUF and 0.16 HUF, for 2004 they were 0.08 HUF and 0.11 HUF. The estimated spread on large trades is, over the whole dataset, $32.35 \%$ higher than the spread on small trades. This difference is also economically significant. ${ }^{10}$ The positive relation we observe is consistent with what other authors find on the interbank market. (Osler et al. 2010).

From a theoretical point of view we would expect the share of the adverse selection component and inventory holding premium on the one hand and the order processing component on the other hand to evolve with trade size in opposite directions: One would assume that the sum of the inventory holding and the adverse selection component increases with the trade size, because large trades are more difficult to offset and potentially contain more information. In contrast, the order processing component is expected to remain constant

\footnotetext{
${ }^{9}$ After estimating equation (5) we performed a t-test on the coefficients of the size-specific dummies to check the significance.

${ }^{10}$ If a trader sells 3 million Euros on the interbank market he would, on average, pay 603,97 EUR under the form of deviation from the midpoint if he submits three orders of one million each. If he submits one large order he would pay, on average, 799,13 EUR.
} 
in absolute terms, as the share of the fixed costs covered by a trade only linearly depends on the trade size.

This is also what we find in the data: while there seems to be no relation between trade size and the absolute size of the order processing component, we find a strong positive relation between trade size and the sum of the absolute adverse selection and inventory holding component. So, the order processing cost is indeed fixed per unit bought/sold, whereas the adverse selection and inventory holding component increases per unit when more units are bought or sold. This results in relatively decreasing order processing costs with trade size, and relative increasing costs for the combined component of inventory and adverse selection costs.

Table 4 summarizes our results for the two- and the three-way decomposition in comparison with previous studies. Despite the different setups of the studies in terms of counterparties, trading mechanisms and sample periods we can draw some interesting conclusions:

Taking the two-way decomposition as a reasonable starting point (see Table 4a) the two studies on minor markets (Bjønnes and Rime 2005 and our study) find shares of the order processing costs of 50 and $43 \%$ respectively, and are thus located at the upper range of estimates of the OPC. Interestingly the two estimates of higher shares of OPC are by McGroarty et al. (2007) on the DEM/USD and EUR/USD market respectively, thus the largest and most liquid FX market. However, one has to keep in mind that we are talking about relative shares. Since the spread is much bigger in minor markets in absolute terms, our $43 \%$ correspond with about 181 EUR, which exceeds the whole estimated spreads (consisting of all three components) for all currencies but the EUR/JPY in the post EMU sample of McGroarty et al. (2007).

The three-way decomposition allows a comparison of the results on the inventory holding and the adverse selection component. Table $4 \mathrm{~b}$ shows the results of our study in comparison with results from previous empirical work. The early studies by Lyons (1995) and Yao (1997) find evidence for an inventory holding premium, but are less comparable (due to the sample period and/or the high share of customer trades). The more comparable analyses, however, still provide inconsistent results. While Mende (2005) and Bjønnes and Rime (2005) do not find any evidence for an inventory holding premium, McGroarty et al. (2007) find an inventory holding component of various size, between 37 and $56 \%$ for the pre-EMU sample, and between 42 and $70 \%$ for the post-EMU period. They also extensively discuss these 
differing results and trace them back to the differences in individual dealer's data and market wide data. Since our dataset is very similar and might even cover a larger share of the market (due to the absence of competing brokerage systems at that time), it is not surprising that our results corroborate with theirs, and provide additional evidence for the presence of an inventory holding premium.

Summing up, and taking into account the difficulties in comparing the various studies, we find an order processing component that is large in absolute terms, but also located at the upper range in relative terms compared to previous studies. Furthermore we find a substantial share of the inventory holding premium, which contradicts the recent studies by Mende (2005) and Bjønnes and Rime (2005), but is in line with the comparable study by McGroarty et al. (2007).

\section{Concluding Remarks}

In this paper we apply the well established spread decomposition model by Huang and Stoll (1997) to a new and large dataset on the Hungarian Forint/Euro market. The main results are in line with existing studies on more liquid markets. Inventory holding costs account on average for $40 \%$ of the spread. Order processing costs and adverse selection costs represent on average respectively $38 \%$ and $21 \%$ of the spread.

Furthermore, we find that the increased trading volume that the market experienced during the transition process coincided with a decreasing spread size. In the end, adverse selection costs became more important. Order processing and inventory holding costs have declined over time.

Finally, we find a close relation between spreads and the order size: The spread considerably increases with order size. While the order processing component remains stable, the other components show a substantial increase.

Summing up, our analysis confirms most of the results from previous theoretical and empirical studies, but also points at the differences between minor interbank market segments with low liquidity, competition and trading activity compared to major currency markets. 


\section{References}

Admati, Anat R. and Paul Pfleiderer (1988). Selling and Trading on Information in Financial Markets, American Economic Review 78, 96-103.

BIS (1996). Triennial Central Bank Survey of Foreign Exchange and Derivatives Market Activity 1995, Bank for International Settlements: Basel.

BIS (2005). Triennial Central Bank Survey of Foreign Exchange and Derivatives Market Activity in 2004, Bank for International Settlements: Basel.

BIS (2010). Triennial Central Bank Survey of Foreign Exchange and Derivatives Market Activity in 2010, Bank for International Settlements: Basel.

Bjønnes, Geir Høidal and Dagfinn Rime (2005). Dealer Behavior and Trading Systems in Foreign Exchange Markets, Journal of Financial Economics 75, 571-605.

Brunnermeier, Markus K., Nagel, Stefan and Pedersen, Lasse H., 2009. "Carry Trades and Currency Crashes." NBER Macroeconomics Annual 2008 23, 313-347.

Copeland, Thomas C., and Dan Galai (1983). Information Effects on the Bid-Ask Spread, Journal of Finance 38, 1457-1469.

Ding, Liang (2009). Bid-Ask Spread and Order Size in the Foreign Exchange Market: An Empirical Investigation, International Journal of Finance and Economics 14, 98-105.

Easley, David and Maureen O'Hara (1987). Price, Trade Size and Information in Securities Markets, Journal of Financial Economics 19, 69-90.

Foucault, Thierry, Kadan, Ohad and Kandel, Eugene (2005). Limit Order Book as a Market for Liquidity, Review of Financial Studies 18, 1171-1217.

George, Thomas J., Gautam Kaul and M. Nimalendran (1991). Estimation of the Bid-Ask Spread and its Components: A New Approach, The Review of Financial Studies 4:4, 623-656.

Gereben, Aron and Norbert Kiss M. (2006). A Brief Overview of the Characteristics of Interbank Forint/Euro Trading, Magyar Nemzeti Bank Bulletin, December 2006, 21-26.

Glosten, Lawrence R., and Paul R. Milgrom (1985). Bid, Ask and Transaction Prices in a Specialist Market with Heterogeneously Informed Traders, Journal of Financial Economics 14, 71-100.

Hansen, Lars P. (1982). Large-Sample Properties of Generalized Method of Moments Estimators, Econometrica 50, 1029-1054

Hartmann, Philipp (1991). Trading Volumes and Transaction Costs in the Foreign Exchange Market, Journal of Banking and Finance 23, 801-824.

Ho, Thomas and Hans R. Stoll (1981). Optimal Dealer Pricing under Transactions and Return Uncertainty, Journal of Financial Economics 9, 47-73.

Huang, Roger D. and Hans R. Stoll (1997). The Components of the Bid-Ask Spread, A General Approach, Review of Financial Studies 10, 995-1034.

Kyle, Albert S. (1985). Continuous Auctions and Insider Trading, Econometrica 53, 13151336.

Linnainmaa, Juhani T. and Ioanid Rosu (2009). Weather and Time Series Determinants of Liquidity in a Limit Order Market, AFA San Francisco Meetings Paper

Lyons, Richard K. (1995). Tests of Microstructural Hypotheses in the Foreign Exchange Market, Journal of Financial Economics 39, 321-351.

Lyons, Richard K. (1998). Profits and Position Control: a Week of FX Dealing, Journal of International Money and Finance 17, 97-115. 
Lyons, Richard K. (2001). The Microstructure Approach to Foreign Exchange, Cambridge MA, MIT Press.

Madhavan, Ananth and Seymour Smidt (1991). A Bayesian Model of Intraday Specialist Pricing, Journal of Financial Economics 14, 3-24.

McGroarty, Frank, Owain ap Gwilym and Stephen Thomas (2007). The Components of Electronic Inter-Dealer Spot FX Bid-Ask Spreads, Journal of Business Finance \& Accounting, 34:9\&10, 1635-1650.

Mende, Alexander (2005). Order Flow Analyses and Foreign Exchange Dealing, Peter Lang Publishing Group: Frankfurt am Main et al.

Naik, Narayan Y., Neuberger, A. and Viswanathan, S (1999). Trade Disclosure Regulation in Markets with Negotiated Trades, Review of Financial Studies, 12, 873-900.

Newey, Whitney K. and West, Kenneth, D. (1987). A Simple, Positive Semi-Definite, Heteroskedasticity and Autocorrelation Consistent Covariance Matrix, Econometrica 55, 703-708.

Osler, Carol L., Mende, Alexander, Menkhoff, Lukas (2010). Price Discovery in Currency Markets, Working Paper, Brandeis University.

Parlour, Christine A. (1998). Price Dynamics in Limit Order Markets. Review of Financial Studies 11, 789-816.

Payne Richard (2005). Informed Trade in Spot Foreign Exchange Markets: an Empirical Investigation, Journal of International Economics 61, 307-329.

Rosu, Ioanid (2009). A Dynamic Model of the Limit Order Book. Review of Financial Studies $22,4604-4641$.

Rime, Dagfinn (2003). E-Trading Systems in Foreign Exchange Markets, New Economy Handbook, Chapter 21, ElsevierScience (USA), 469-504.

Stoll, Hans R. (1978), The Pricing of Security Dealer Services: An Empirical Study of NASDAQ Stocks, The Journal of Finance 33:4, 1153-1172.

Stoll, Hans R. (1989), Inferring the Components of the Bid-Ask Spread: Theory and Empirical Tests, The Journal of Finance 44:1, 115-134.

Stoll, Hans R. (2003). Market Microstructure, in: Handbook of the Economics of Finance, (edited by G. Constantinides, R.M. Stulz, and M. Harris), vol. 1, 553-604.

Van Ness, Bonnie F., Robert A. Van Ness and Richard S. Warr (2001). How Well do Adverse Selection Components Measure Adverse Selection? Financial Management 30, 77-98

Yao, Jian (1997) Market Making in the Interbank Foreign Exchange Market, Working Paper S-98-3, Stern School of Business, New York University. 


\section{TABLES AND FigureS}

TABLE 1: Descriptive Statistics of the Dataset

\begin{tabular}{|c|c|c|c|}
\hline & Whole sample & 2003 & 2004 \\
\hline Number of quotes & 437,420 & 193,447 & 243,973 \\
\hline Number of trades ${ }^{a, b}$ & 72,622 & 31,978 & 40,644 \\
\hline Average trade size & 1,304,398 EUR & 1,339,827 EUR & 1,276,523 EUR \\
\hline Trades $\leq 1$ million $€$ & $80.38 \%$ & $78.89 \%$ & $81.55 \%$ \\
\hline Trades $>1$ million $€$ and $<3$ million $€$ & $13.79 \%$ & $14.50 \%$ & $13.23 \%$ \\
\hline Trades $\geq 3$ million $€$ & $5.83 \%$ & $6.61 \%$ & $5.22 \%$ \\
\hline Average number of quotes per day & 881.90 & 806.03 & 953.02 \\
\hline Average number of trades per day & 146.42 & 133.24 & 158.77 \\
\hline Average daily trading volume (million $€$ ) & 190.98 & 178.52 & 202.67 \\
\hline Average spread (basis points) ${ }^{c}$ & 4.18 & 5.20 & 3.42 \\
\hline
\end{tabular}

${ }^{a}$ The buy and sell are together counted as 1 trade

${ }^{\mathrm{b}}$ On days with a minimum volume and during the office hours

${ }^{\mathrm{c}}$ Estimated with the two-way decomposition 
TABLE 2: Two-Way Decomposition of the Spread

\begin{tabular}{|c|c|c|c|c|c|c|}
\hline & Half-Spread & $\begin{array}{c}\lambda * \text { Half- } \\
\text { Spread }\end{array}$ & $\mathrm{R}^{2}$ & Spread & $\mathrm{ASC}+\mathrm{IHC}^{\mathrm{a}}$ & $\mathrm{OPC}^{\mathrm{b}}$ \\
\hline $\begin{array}{l}\text { Whole } \\
\text { sample }\end{array}$ & $\begin{array}{l}0.053 \\
(64.43) * * *\end{array}$ & $\begin{array}{c}0.031 \\
(59.50) * * *\end{array}$ & 0.10 & 0.106 & $\begin{array}{c}0.061 \\
57.42 \%\end{array}$ & $\begin{array}{c}0.045 \\
42.58 \%\end{array}$ \\
\hline 2003 & $\begin{array}{l}0.067 \\
(48.31) * * *\end{array}$ & $\begin{array}{c}0.038 \\
(41.55) * * *\end{array}$ & 0.11 & 0.133 & $\begin{array}{c}0.075 \\
56.43 \%\end{array}$ & $\begin{array}{c}0.058 \\
43.57 \%\end{array}$ \\
\hline 2004 & $\begin{array}{l}0.043 \\
(47.37) * * *\end{array}$ & $\begin{array}{l}0.025 \\
(47.01)^{* * *}\end{array}$ & 0.10 & 0.086 & $\begin{array}{c}0.050 \\
57.87 \%\end{array}$ & $\begin{array}{c}0.036 \\
42.13 \%\end{array}$ \\
\hline 2003 jan-jun & $\begin{array}{l}0.067 \\
(29.58) * * *\end{array}$ & $\begin{array}{l}0.036 \\
(24.87) * * *\end{array}$ & 0.09 & 0.134 & $\begin{array}{c}0.073 \\
54.16 \%\end{array}$ & $\begin{array}{c}0.062 \\
45.84 \%\end{array}$ \\
\hline 2003 jul-dec & $\begin{array}{l}0.066 \\
(43.97) * * *\end{array}$ & $\begin{array}{l}0.038 \\
(36.19)^{* * *}\end{array}$ & 0.13 & 0.132 & $\begin{array}{c}0.077 \\
58.15 \%\end{array}$ & $\begin{array}{c}0.056 \\
41.85 \%\end{array}$ \\
\hline 2004 jan-jun & $\begin{array}{l}0.054 \\
(31.98) * * *\end{array}$ & $\begin{array}{l}0.031 \\
(33.58) * * *\end{array}$ & 0.10 & 0.109 & $\begin{array}{c}0.063 \\
57.62 \%\end{array}$ & $\begin{array}{c}0.046 \\
42.38 \%\end{array}$ \\
\hline 2004 jul-dec & $\begin{array}{c}0.033 \\
(46.96) * * *\end{array}$ & $\begin{array}{l}0.019 \\
(38.68) * * *\end{array}$ & 0.13 & 0.066 & $\begin{array}{c}0.038 \\
57.41 \%\end{array}$ & $\begin{array}{c}0.028 \\
42.59 \%\end{array}$ \\
\hline & Half-Spread & $\begin{array}{l}(\lambda-1)^{*} \text { Half- } \\
\text { Spread }\end{array}$ & $\mathrm{R}^{2}$ & Spread & $\mathrm{ASC}+\mathrm{IHC}^{\mathrm{a}}$ & $\mathrm{OPC}^{\mathrm{b}}$ \\
\hline Small trades & $\begin{array}{l}0.051 \\
(60.64) * * *\end{array}$ & $\begin{array}{c}-0.023 \\
(-29.34) * * *\end{array}$ & 0.10 & 0.102 & $\begin{array}{c}0.056 \\
54.80 \%\end{array}$ & $\begin{array}{c}0.046 \\
45.20 \%\end{array}$ \\
\hline $\begin{array}{l}\text { Medium } \\
\text { trades }\end{array}$ & $\begin{array}{l}0.061 \\
(36.78) * * *\end{array}$ & $\begin{array}{l}-0.023 \\
(-19.81) * * *\end{array}$ & 0.10 & 0.123 & $\begin{array}{c}0.078 \\
63.23 \%\end{array}$ & $\begin{array}{c}0.045 \\
36.77 \%\end{array}$ \\
\hline Large trades & $\begin{array}{l}0.067 \\
(30.75) * * *\end{array}$ & $\begin{array}{l}-0.022 \\
(-13.35) * * *\end{array}$ & 0.10 & 0.135 & $\begin{array}{c}0.090 \\
66.79 \%\end{array}$ & $\begin{array}{c}0.045 \\
33.21 \%\end{array}$ \\
\hline
\end{tabular}

${ }^{\text {a }}$ Adverse selection component + inventory holding component (in absolute (HUF) and relative values)

${ }^{\mathrm{b}}$ Order processing component (in absolute (HUF) and relative values)

*** indicates significance at the $1 \%$ level, t-values in parentheses. 
TABLE 3: Three-Way Decomposition of the Spread

\begin{tabular}{|c|c|c|c|c|c|c|c|c|c|}
\hline & $(1-2 \pi)$ & Half-Spread & $\begin{array}{c}(\alpha+\beta-1) \\
* \text { Half-Spread }\end{array}$ & $\begin{array}{l}\alpha \\
* \text { Half-Spread * } \\
(1-2 \pi)\end{array}$ & $\pi$ & Spread & $\mathrm{OPC}^{\mathrm{a}}$ & $\mathrm{ASC}^{\mathrm{b}}$ & $\mathrm{IHC}^{\mathrm{c}}$ \\
\hline \multirow[b]{2}{*}{ Whole sample } & 0.454 & 0.054 & -0.021 & 0.005 & \multirow{2}{*}{0.27} & \multirow{2}{*}{0.107} & 0.041 & 0.023 & 0.043 \\
\hline & $(136.36) * * *$ & $(89.34) * * *$ & $(-31.98) * * *$ & $(8.74) * * *$ & & & $38.34 \%$ & $21.57 \%$ & $40.09 \%$ \\
\hline \multirow{2}{*}{2003} & 0.471 & 0.067 & -0.027 & 0.006 & \multirow{2}{*}{0.26} & \multirow{2}{*}{0.134} & 0.054 & 0.024 & 0.057 \\
\hline & $(94.70) * * *$ & $(61.35) * * *$ & $(-22.77) * * *$ & $(5.09) * * *$ & & & $39.95 \%$ & $17.65 \%$ & $42.40 \%$ \\
\hline \multirow{2}{*}{2004} & \multirow{2}{*}{$\begin{array}{l}0.441 \\
\quad(98.38) * * *\end{array}$} & \multirow{2}{*}{$\begin{array}{l}0.043 \\
(67.51) * * *\end{array}$} & -0.016 & 0.005 & \multirow{2}{*}{0.28} & \multirow{2}{*}{0.087} & 0.032 & 0.023 & 0.032 \\
\hline & & & $(-23.47) * * *$ & $(7.83) * * *$ & & & $37.10 \%$ & $26.32 \%$ & $36.59 \%$ \\
\hline \multirow{2}{*}{2003 jan-jun } & 0.473 & 0.068 & -0.029 & 0.005 & \multirow{2}{*}{0.26} & \multirow{2}{*}{0.136} & 0.058 & 0.021 & 0.056 \\
\hline & $(66.42) * * *$ & $(38.50) * * *$ & $(-15.30) * * *$ & $(2.88) * * *$ & & & $42.72 \%$ & $15.83 \%$ & $41.46 \%$ \\
\hline \multirow{2}{*}{2003 jul-dec } & \multirow{2}{*}{$\begin{array}{l}0.469 \\
(67.50) * * *\end{array}$} & \multirow{2}{*}{$\begin{array}{l}0.066 \\
(50.20) * * *\end{array}$} & -0.025 & 0.006 & \multirow{2}{*}{0.27} & \multirow{2}{*}{0.133} & 0.049 & 0.026 & 0.057 \\
\hline & & & $(-17.37) * * *$ & $(4.57) * * *$ & & & $37.28 \%$ & $19.42 \%$ & $43.30 \%$ \\
\hline \multirow{2}{*}{2004 jan-jun } & \multirow{2}{*}{$\begin{array}{l}0.455 \\
(70.13) * * *\end{array}$} & \multirow{2}{*}{$\begin{array}{l}0.055 \\
(45.97) * * *\end{array}$} & -0.021 & 0.006 & \multirow{2}{*}{0.27} & \multirow{2}{*}{0.110} & 0.042 & 0.025 & 0.044 \\
\hline & & & $(-16.22) * * *$ & $(4.68) * * *$ & & & $37.85 \%$ & $22.40 \%$ & $39.75 \%$ \\
\hline \multirow{2}{*}{2004 jul-dec } & \multirow{2}{*}{$\begin{array}{l}0.428 \\
(69.14) * * *\end{array}$} & \multirow{2}{*}{$\begin{array}{l}0.033 \\
(56.53) * * *\end{array}$} & -0.012 & 0.0045 & \multirow{2}{*}{0.29} & \multirow{2}{*}{0.067} & 0.025 & 0.021 & 0.021 \\
\hline & & & $(-19.62) * * *$ & $(7.59) * * *$ & & & $36.87 \%$ & $31.35 \%$ & $31.78 \%$ \\
\hline
\end{tabular}

a Order processing component (in absolute (HUF) and relative values)

${ }^{\mathrm{b}}$ Adverse selection component (in absolute (HUF) and relative values)

${ }^{\mathrm{c}}$ Inventory holding component (in absolute and relative values)

$* * *$ indicates significance at the $1 \%$ level, $\mathrm{t}$-values in parentheses. 
TABLE 4a: Comparison with selected previous studies (Two-way decomposition)

\begin{tabular}{|c|c|c|c|c|c|c|c|c|}
\hline & \multirow[t]{2}{*}{ Market } & \multirow[t]{2}{*}{ Period } & \multirow[t]{2}{*}{ \# obs. } & \multirow[t]{2}{*}{ Types of trades } & \multirow[t]{2}{*}{$\mathrm{CP}^{\mathrm{a}}$} & \multicolumn{2}{|c|}{ Spread components } & \multirow[t]{2}{*}{ Market Fraction } \\
\hline & & & & & & $\mathrm{IHC}+\mathrm{ASC}^{\mathrm{b}}$ & $\mathrm{OPC}^{\mathrm{b}}$ & \\
\hline \multicolumn{9}{|l|}{ Minor markets } \\
\hline This study & HUF/EUR & $\begin{array}{l}\text { Jan } 2003- \\
\text { Dec } 2004 \\
\text { (2 years) }\end{array}$ & 71,630 & $\begin{array}{l}\text { Complete trading on } \\
\text { Reuters D3000 }\end{array}$ & IB & $57 \%$ & $43 \%$ & $\begin{array}{l}\text { Whole (electronic) } \\
\text { market }\end{array}$ \\
\hline $\begin{array}{l}\text { Bjønnes/Rime } \\
(2005)^{\text {c }}\end{array}$ & NOK/DEM & $\begin{array}{l}\text { Feb } 1998 \\
(5 \text { days })\end{array}$ & 144 & Direct and indirect trades & $\mathrm{C}+\mathrm{IB}$ & $50 \%$ & $50 \%$ & $\begin{array}{l}\text { Market maker, } \\
\text { customer share of } \\
18 \%\end{array}$ \\
\hline \multicolumn{9}{|l|}{ Major markets } \\
\hline Lyons (1995) & DEM/USD & $\begin{array}{l}\text { Aug } 1992 \\
(5 \text { days })\end{array}$ & 838 & $\begin{array}{c}\text { Direct and brokered } \\
\text { trades }\end{array}$ & IB & $49 \%$ & $51 \%$ & $\begin{array}{l}\text { Large share of } \\
\text { indirect trades }\end{array}$ \\
\hline $\begin{array}{l}\text { Bjønnes/Rime } \\
(2005)^{d}\end{array}$ & DEM/USD & $\begin{array}{c}\text { Feb } 1998 \\
\text { (5 days) }\end{array}$ & $169-430$ & Direct and indirect trades & $(\mathrm{C}+) \mathrm{IB}$ & $81 \%$ & $19 \%$ & $\begin{array}{l}\text { One dealer, customer } \\
\text { share of } 3 \%\end{array}$ \\
\hline \multirow{5}{*}{$\begin{array}{l}\text { McGroarty et } \\
\text { al. (2007) }\end{array}$} & USD/JPY & Aug-Sept 2008 & 399,124 & Complete EBS trading & IB & $72 \%$ & $28 \%$ & \multirow{5}{*}{$\begin{array}{l}\text { Major fraction of } \\
\text { electronic market }\end{array}$} \\
\hline & USD/CHF & (20 days) & 42,952 & & & $86 \%$ & $14 \%$ & \\
\hline & DEM/USD & & 484,005 & & & $56 \%$ & $44 \%$ & \\
\hline & DEM/JPY & & 128,064 & & & $91 \%$ & $9 \%$ & \\
\hline & DEM/CHF & & 73,898 & & & $74 \%$ & $26 \%$ & \\
\hline McGroarty et & USD/JPY & Aug-Sept 2009 & 225,825 & Complete EBS trading & IB & $64 \%$ & $36 \%$ & \multirow{5}{*}{$\begin{array}{l}\text { Major fraction of } \\
\text { electronic market }\end{array}$} \\
\hline \multirow{4}{*}{ al. $(2007)$} & $\mathrm{USD} / \mathrm{CHF}$ & (20 days) & 72,939 & & & $81 \%$ & $19 \%$ & \\
\hline & EUR/USD & & 310,300 & & & $45 \%$ & $55 \%$ & \\
\hline & EUR/JPY & & 42,743 & & & $79 \%$ & $21 \%$ & \\
\hline & EUR/CHF & & 29,654 & & & $67 \%$ & $33 \%$ & \\
\hline
\end{tabular}

\footnotetext{
${ }^{a}$ Counterparty: $\mathrm{C}=$ customer, $\mathrm{IB}=$ interbank

b IHC: inventory component, ASC: adverse selection component, OPC: order processing component

c Dealer 1 in the sample
}

${ }^{\mathrm{d}}$ Dealer 3 in the sample, dealers 2 and 4 trade less in DEM/USD and are not considered here.

TABLE 4b: Comparison with selected previous studies (Three-way decompositions) 


\begin{tabular}{|c|c|c|c|c|c|c|c|c|c|}
\hline & \multirow[t]{2}{*}{ Market } & \multirow[t]{2}{*}{ Period } & \multirow[t]{2}{*}{ \# obs. } & \multirow[t]{2}{*}{ Types of trades } & \multirow[t]{2}{*}{$\mathrm{CP}^{\mathrm{a}}$} & \multicolumn{3}{|c|}{ Spread components } & \multirow[t]{2}{*}{ Market Fraction } \\
\hline & & & & & & $\mathrm{IHC}^{\mathrm{b}}$ & $\mathrm{ASC}^{\mathrm{b}}$ & $\mathrm{OPC}^{\mathrm{b}}$ & \\
\hline \multicolumn{10}{|l|}{ Minor markets } \\
\hline This study & HUF/EUR & $\begin{array}{c}\text { Jan } 2003- \\
\text { Dec } 2004 \\
\text { (2 years) }\end{array}$ & 71,630 & $\begin{array}{l}\text { Complete trading on } \\
\text { Reuters D3000 }\end{array}$ & IB & $40 \%$ & $21 \%$ & $38 \%$ & $\begin{array}{l}\text { Whole (electronic) } \\
\text { market }\end{array}$ \\
\hline $\begin{array}{l}\text { Bjønnes/Rime } \\
(2005) \mathrm{c}\end{array}$ & NOK/DEM & $\begin{array}{l}\text { Feb } 1998 \\
(5 \text { days })\end{array}$ & 144 & Direct and indirect trades & $\mathrm{C}+\mathrm{IB}$ & $0 \%$ & $49 \%$ & $51 \%$ & $\begin{array}{l}\text { Market maker, } \\
\text { customer share of } 18 \%\end{array}$ \\
\hline \multicolumn{10}{|l|}{ Major markets } \\
\hline Lyons (1995) & DEM/USD & $\begin{array}{l}\text { Aug } 1992 \\
\text { (5 days) }\end{array}$ & 838 & Direct and indirect trades & IB & $30 \%$ & $15 \%$ & $45 \%$ & \multirow{3}{*}{$\begin{array}{l}\text { Large share of indirect } \\
\text { trades } \\
\text { High share of customer } \\
\text { trades ( } 75 \% \text { of profits) }\end{array}$} \\
\hline Yao (1998) & DEM/USD & $\begin{array}{l}\text { Nov-Dec } 1995 \\
\quad(25 \text { days })\end{array}$ & 4,518 & Direct and indirect trades & $\mathrm{C}+\mathrm{IB}$ & $70 \%$ & $23 \%$ & $7 \%$ & \\
\hline Mende (2005) & EUR/USD & $\begin{array}{l}\text { Jul-Nov } 2001 \\
\quad(87 \text { days })\end{array}$ & 2,859 & Direct and indirect trades & $\mathrm{C}+\mathrm{IB}$ & $0 \%$ & $<40 \%{ }^{\mathrm{d}}$ & $>60 \%{ }^{d}$ & \\
\hline $\begin{array}{l}\text { Bjønnes/Rime } \\
(2005)^{d}\end{array}$ & DEM/USD & $\begin{array}{l}\text { Feb } 1998 \\
(5 \text { days })\end{array}$ & $169-430$ & Direct and indirect trades & $(\mathrm{C}+) \mathrm{IB}$ & $0 \%$ & $72 \%$ & $28 \%$ & Customer share of $3 \%$ \\
\hline \multirow{5}{*}{$\begin{array}{l}\text { McGroarty et } \\
\text { al. (2007) }\end{array}$} & USD/JPY & Aug-Sept 2008 & 399,124 & \multirow[t]{5}{*}{ Complete EBS trading } & \multirow[t]{5}{*}{ IB } & $43 \%$ & $29 \%$ & $28 \%$ & \multirow{5}{*}{$\begin{array}{l}\text { major fraction of } \\
\text { electronic market }\end{array}$} \\
\hline & $\mathrm{USD} / \mathrm{CHF}$ & (20 days) & 42,952 & & & $56 \%$ & $29 \%$ & $15 \%$ & \\
\hline & DEM/USD & & 484,005 & & & $38 \%$ & $25 \%$ & $37 \%$ & \\
\hline & DEM/JPY & & 128,064 & & & $50 \%$ & $36 \%$ & $13 \%$ & \\
\hline & $\mathrm{DEM} / \mathrm{CHF}$ & & 73,898 & & & $37 \%$ & $45 \%$ & $15 \%$ & \\
\hline \multirow{5}{*}{$\begin{array}{l}\text { McGroarty et } \\
\text { al. (2007) }\end{array}$} & USD/JPY & Aug-Sept 2009 & 225,825 & \multirow[t]{5}{*}{ Complete EBS trading } & \multirow[t]{5}{*}{ IB } & $61 \%$ & $7 \%$ & $32 \%$ & \multirow{5}{*}{$\begin{array}{l}\text { major fraction of } \\
\text { electronic market }\end{array}$} \\
\hline & $\mathrm{USD} / \mathrm{CHF}$ & (20 days) & 72,939 & & & $70 \%$ & $17 \%$ & $13 \%$ & \\
\hline & EUR/USD & & 310,300 & & & $42 \%$ & $9 \%$ & $49 \%$ & \\
\hline & EUR/JPY & & 42,743 & & & $65 \%$ & $18 \%$ & $16 \%$ & \\
\hline & EUR/CHF & & 29,654 & & & $45 \%$ & $33 \%$ & $21 \%$ & \\
\hline
\end{tabular}

${ }^{\text {a }}$ Counterparty: $\mathrm{C}=$ customer, $\mathrm{IB}=$ interbank

b IHC: inventory component, ASC: adverse selection component, OPC: order processing component

c Dealer 1 in the sample

d Dealer 3 in the sample, dealers 2 and 4 trade less in DEM/USD and are not considered here. 
FIGURE 1: Daily volume and daily average quote on the HUF/EUR market for 2003 and 2004

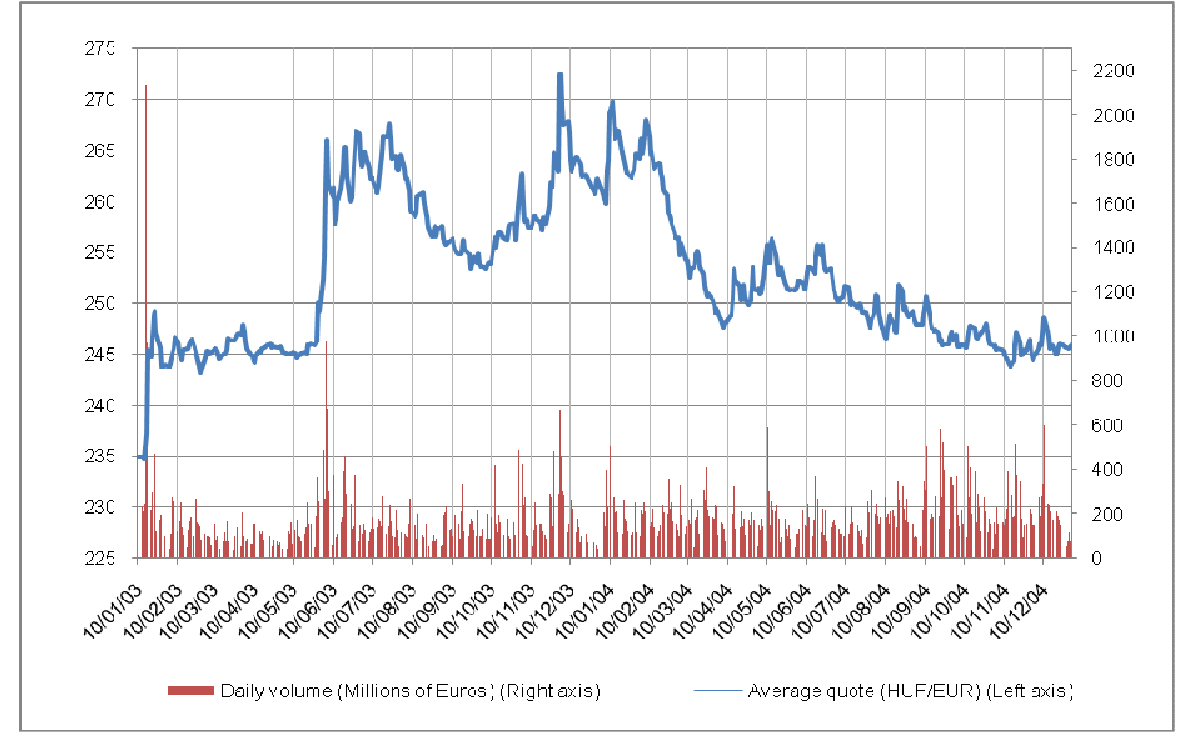

FIGURE 2: Decomposition by Half-Year

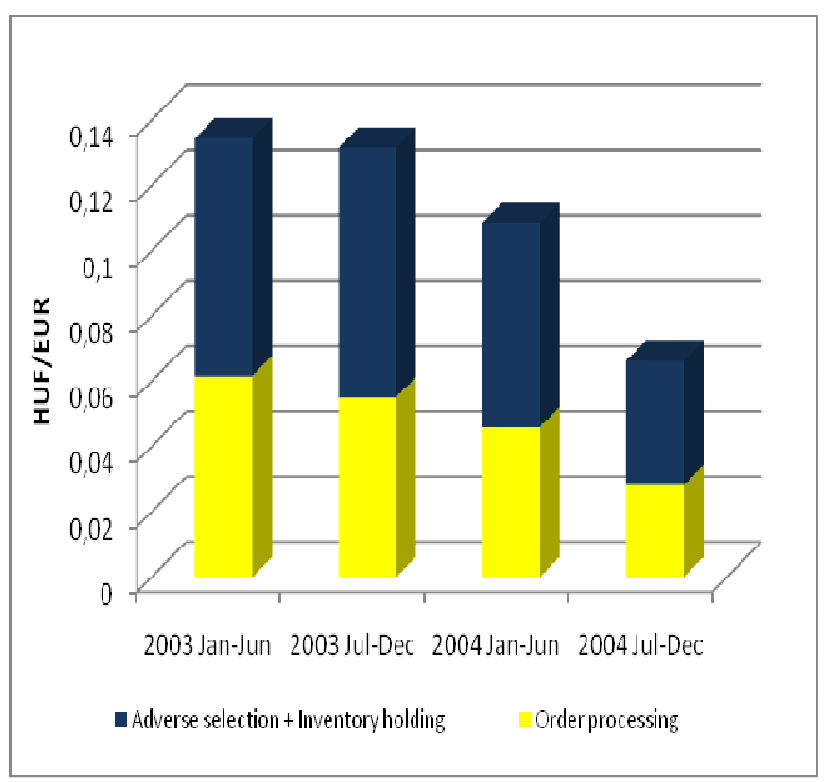

FIGURE 3: Decomposition by Trade Size

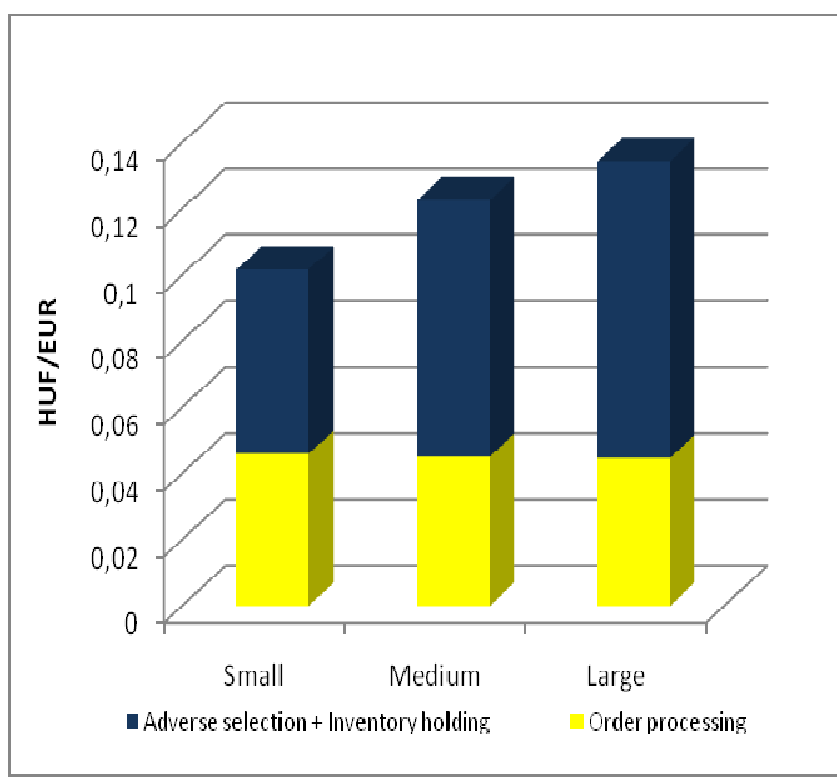

